\title{
Performance of Pomegranate (Punica granatum L.) Cultivars under Subtropical Conditions of Jammu, India
}

\author{
Deep Ji Bhat*, V.K. Wali, Nirmal Sharma, Parshant Bakshi, \\ Mahital Jamwal and Rajesh Kumar
}

Sher-e-Kashmir University of Agriculture Sciences and Technology of Jammu, Chatha, Jammu, J\&K, India

*Corresponding author

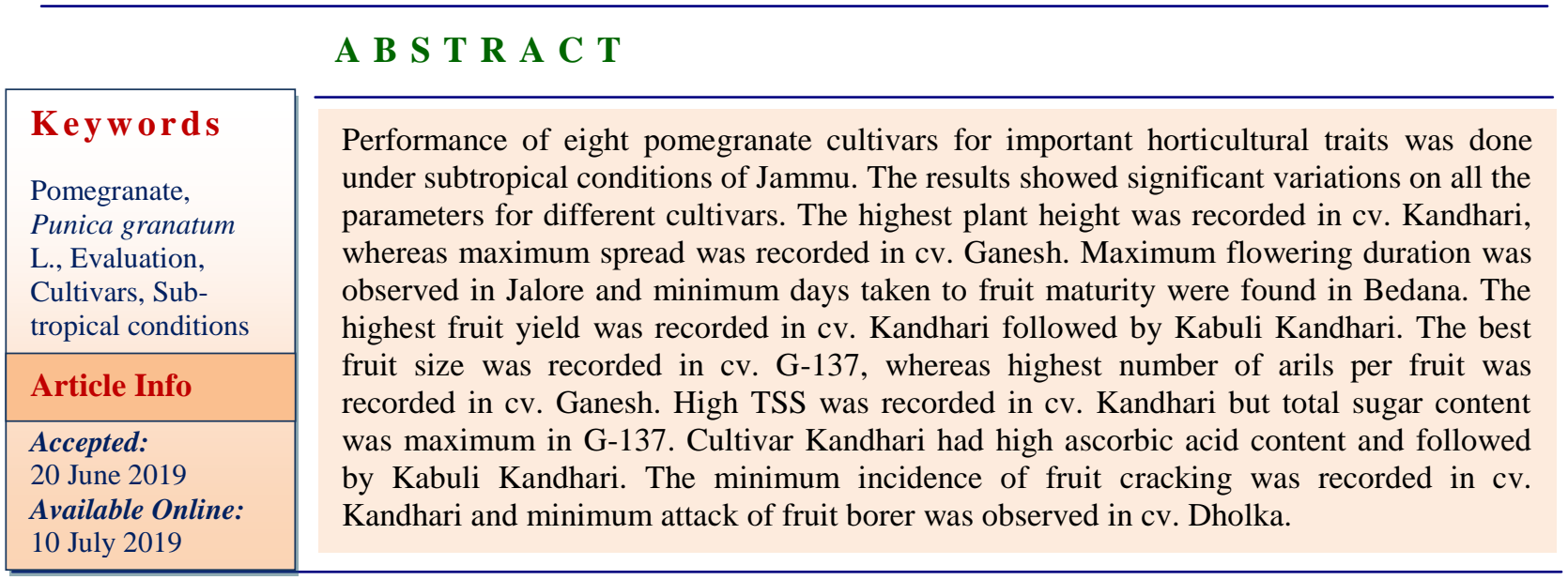

\section{Introduction}

Pomegranate (Punica granatum L), belonging to family punicaceae is one of the oldest known edible fruits. It is an important fruit crop of arid and semi-arid regions of the world. It is a highly remunerative crop for replacing subsistence farming and alleviating poverty (Jadhav and Sharma, 2007). It is thought to be indigenous to the Iran from where it spread to the Mediterranean countries. The unique plasticity of this fruit crop is evident from the threshold limits it exhibits for higher $\left(44^{\circ} \mathrm{C}\right)$ and lower $\left(-12^{\circ} \mathrm{C}\right)$ temperature (Westwood, 1978). It is referred to as 'super fruit' because of its high nutritive value, high antioxidant capacity, high potentially bioactive compounds, chemopreventive properties having medicinal value and high consumer's appeal (Hertog et al., 1997). The edible portion of pomegranate is an excellent dietary source as it contains a significant proportion of organic acids, soluble acids, polysaccharides, vitamins, fatty acids and mineral elements of nutritional significance. Pomegranate juice has shown a threefold higher antioxidant capacity than red wine or green tea (Gil et al., 2000) and 2, 6, 8 fold higher capacity than those detected in 
grape, grapefruit and orange juices, respectively (Rosenblat and Aviram, 2006). The fruit has a consumer preference due to its attractive, juicy, sweet acidic and refreshing arils. Besides the fruit being consumed fresh, it can also be processed into juice, syrup, squash, wine and anardana (an acidulant product). The juice is useful for patients suffering from leprosy. Bark of the plant and rind of fruit is commonly used in dysentery and diarrhea. The rind is also used as dyeing material for cloth. Presently it is grown commercially in Egypt, Iran, Spain, Morocco, Syria, Afghanistan, Turkmenistan, Pakistan (Baluchistan) and India. It is also grown to some extent in Myanmar, China, Japan and USA (California). It has now been taken to most parts of the tropics and subtropics. The best quality fruits are produced in areas with cool winters and hot dry summers and it does not fruit well in very humid climate. India is one of the leading producers of fruits in the world. Fruit crops are cultivated in India over 63.83 million ha with a total production of 748.78 million tones/ annum and productivity of $11.7 \mathrm{t} / \mathrm{ha}$. During 2017-18, the pomegranate was cultivated over 2.34 lakh hectare with a total production of 28.45 lakh MT and productivity of $12.16 \mathrm{t} / \mathrm{ha}$ in India (Anonymous, 2012). Unfortunately, about 25$40 \%$ of the total fruits produced in the country are lost every year. This is chiefly due to improper post harvest handling operations and this has resulted in wide gap between the gross production and net availability of fruits. The area, production and export of pomegranate by 2025 is expected to reach 7.5 lakh ha, 114 lakh tones and 83,800 tonnes respectively compared to 1.25 lakh ha, 11.4 lakh tones and 12,030 tonnes in 2005. In India, important pomegranate growing states are Maharashtra, Gujarat, Andhra Pradesh, Karnataka, Tamil Nadu and Rajasthan. Maharashtra state is considered as 'pomegranate basket of India' contributing more than $70 \%$ of the total area under pomegranate followed by Karnataka and Andhra Pradesh. In Maharashtra, production of pomegranate is mainly concentrated in the Western Maharashtra region and the Marathwada region. Pomegranates are commercially cultivated in Solapur, Sangli, Nashik, Ahmednagar, Pune, Dhule, Aurangabad, Satara, Osmanabad and Latur districts. In Jammu region of Jammu and Kashmir, pomegranate cultivation is meager and farmers often take up cultivation of mango, litchi or guava, however, ample scope exists for cultivation of pomegranate in Kathua, Samba, Jammu, Rajouri, Akhnoor and Poonch regions. The major reasons for non-adoption of the pomegranate cultivation are non-availability of good quality planting material, lack of standardization of cultivars and agronomic practices. Therefore in the present study effort was made to collect the promising pomegranate cultivars, grow them under Jammu subtropics and evaluate their performance to decide the cultivars performing best under local climatic conditions.

\section{Materials and Methods}

Study was undertaken during 2013-14 to evaluate the performance of some pomegranate cultivars under sub-tropical climate of Jammu at Research Farm, Udheywalla campus, of SKUAST-J. The varieties viz., 'Kandhari, Kandhari Kabuli, Bedana, Ganesh, G-137, Dholka, Jalore Seedless and Local Selection were observed for important vegetative, flowering and fruit characteristics. Besides the incidence of fruit cracking and anar butterfly was also recorded on different cultivars. Planting was done at the distance of $4 \times 4 \mathrm{~m}$ and uniform cultural practices were provided for all cultivates. The observations were recorded on vegetative growth (plant spread, plant height and duration of flowering), fruit characteristics (fruit weight, fruit diameter, fruit length, fruit 
diameter, acidity, ascorbic acid, reducing sugar, total sugar, juice content, maturity index (MI), TSS/Acid ratio and yield per tree. Tree height was recorded with the help of marked bamboo stick/ measuring staff from the ground surface to the maximum height attained by the plant and recorded in metre (m). Tree spread was recorded for each tree by putting the marked bamboo stick horizontally with the tree from east-west and north-south and mean spread was worked out in metre $(\mathrm{m})$. Flowering duration was recorded as the interval between the date when the first flower opened and the date on which last flower opened and expressed as number of days. Similarly, duration from fruit maturity was recorded as the interval between the date when the flowers set fruit and the date on which fruit was harvested and expressed as number of days. For recording fruit characters, twenty fruits of each cultivar were individually analyzed for physical parameters. Fruits were weighted in the air on a Sartorius balance of accuracy of $0.001 \mathrm{~g}$. Fruit volume was calculated by a liquid displacement method. The length and diameter of the fruit and calyx were measured with a Mitutoyo digital vernier caliper. The measurement of fruit length was made on the polar axis i.e. between the apex and the end of stem. The maximum width of the fruit, as measured in the direction perpendicular to the polar axis, is defined as the diameter. After measuring the whole fruit size, the arils were manually separated from the fruits, and total arils and peel per fruit were measured as above. The measurements of the peel thickness were made using the Mitutoyo digital vernier calliper. Then the juices were analyzed for major chemical composition. The total soluble solids (TSS) of the fruit pulp was recorded with the help of Erma hand refractometer $\left(0-32^{\circ} \mathrm{B}\right)$ according to standard procedure as given in A.O.A.C (1995) in terms of degree Brix $\left({ }^{\circ} \mathrm{B}\right)$ at room temperature. A temperature correction was applied when the readings were taken at a temperature other than $20^{\circ} \mathrm{C}$. The refractometer was calibrated with double distilled water before use. Titratable acidity in fresh fruits was determined by the method as suggested in A.O.A.C (1995). The results were expressed as per cent total titratable acidity. Total sugars were calculated by the procedure described in A.O.A.C. (1995). The standard method as suggested by A.O.A.C (1995) using 2, 6-dichlorophenol indophenols $(0.04 \%)$ was followed for estimation of ascorbic acid. The total sugars were estimated according to the method described by Ranganna (2001). Results were expressed as $g$ per $100 \mathrm{~g}$ of juice. Results were expressed as $\mathrm{mg}$ per $100 \mathrm{~g}$ of juice. The data were statistically analyzed using RBD by OPSTAT.

\section{Results and Discussion}

\section{Tree characters}

The data pertaining to tree characters of eight pomegranate cultivars is presented in Table 1. Plant height ranged between $2.13 \mathrm{~m}$ in Local Selection to $2.63 \mathrm{~m}$ in Kandhari. However, the maximum plant height recorded in cultivar Kandhari was statistically at par with the plant height recorded as $2.55 \mathrm{~m}$ in Dholka and Kabuli Kandhari and $2.50 \mathrm{~m}$ in Bedana and Jalore Seedless. Highest plant spread, north south $\mathrm{x}$ eat west was recorded as $1.85 \mathrm{~m} \mathrm{x}$ $1.83 \mathrm{~m}$ in Ganesh followed by $1.75 \times 1.80 \mathrm{~m}$ in Kabuli Kandhari. The minimum plant spread was recorded as $1.25 \mathrm{x} 1.32 \mathrm{~m}$ in Local Selection. Similar type of variation in plant height and plant spread has been reported in pomegranate (Sharma and Bist, 2005). The slight variations among different studies may be attributed to the genetic makeup of cultivars, agroclimatic conditions, nutritional status of soil and cultural practices. The flowering duration ranged between 40 days in Kandhari and 48 days in Bedana. Flowering in Ganesh, Dholka, G-137 and Jalore Seedless 
did not stop completely and few flowers kept on appearing even after the flowering in other cultivars stopped completely. Similar results under North Indian conditions were reported by Mir et al., (2007). The time and duration of flowering appeared to be varietal characteristic which may be due to their genetic constitution of a genotype, however, flowering duration is also affected by the agro-climatic conditions. Time taken from fruit set to fruit maturity ranged between 143 -168 days. The minimum duration from fruit set to fruit maturity was taken by the cultivar Bedana, whereas, Local Selection took maximum duration from fruit set to maturity. Highest fruit yield was recorded as 9.80 $\mathrm{Kg} /$ plant in cultivar Kandhari which was statistically higher than rest of the cultivar. Sinha (2012) also reported 61-130 days from full bloom to maturity in different pomegranate cultivars in North Indian conditions.

\section{Fruit characters}

Average fruit weight ranged between $132 \mathrm{~g}$ in Local Selection to $296 \mathrm{~g}$ in Ganesh. The highest fruit weight of cv. Ganesh was statistically at par with that of $294.0 \mathrm{~g}$ in G137 and 290.0g in Dholka and Bedana.
Similarly fruit size (length $\mathrm{x}$ breadth) ranged between $6.05 \times 5.90 \mathrm{~cm}$ in Local Selection to $7.60 \times 7.32 \mathrm{~cm}$ in G-137 which was closely followed by $7.60 \times 7.30 \mathrm{~cm}$ in Ganesh. Maximum number of arils was recorded as 422 in G-137 followed by 410 in Ganesh and 407 in Kandhari. Wetzstein et al., (2011) have also recorded total number arils per fruit between 201 and 985 for different pomegranate cultivars. Number of arils per fruit is a varietal character and varies from cultivar to cultivar. Total soluble solids $\left({ }^{\circ} \mathrm{B}\right)$ ranged between $12.50^{\circ} \mathrm{B}$ in Local Selection to $15.60^{\circ} \mathrm{B}$ in Kandhari. The highest TSS content of cv. Kandhari was statistically at par with TSS content of $15.32^{\circ} \mathrm{B}$ in Dholka and $15.45^{\circ} \mathrm{B}$ in Kabuli Kandhari. Higher TSS content in a genotype is considered as good character while exercising selection for table as well as processing purpose. The present findings are in agreement with those obtained by Hamouda et al., (2014). Total sugars content ranged between $8.45 \%$ in Local Selection to $9.02 \%$ in G-137. Wani et al., (2012) also reported 6.00 per cent to 10.12 per cent reducing sugars in some promising selections of wild pomegranate in Central Kashmir. Pomegranate fruits have been reported to develop sweeter taste under hotter climate (Patil and Karale, 1992) (Table 2).

Table.1 Tree characters of pomegranate cultivars

\begin{tabular}{|c|c|c|c|c|c|c|}
\hline \multirow[t]{2}{*}{ Cultivar } & \multirow[t]{2}{*}{ Plant height (m) } & \multicolumn{2}{|c|}{ Plant spread (m) } & \multirow{2}{*}{$\begin{array}{c}\text { Flowering } \\
\text { duration } \\
\text { (Days) }\end{array}$} & \multirow{2}{*}{$\begin{array}{l}\text { Duration from } \\
\text { fruit set to } \\
\text { maturity (Day) }\end{array}$} & \multirow{2}{*}{$\begin{array}{c}\text { Fruit yield } \\
\text { (kg/plant) }\end{array}$} \\
\hline & & EW & NS & & & \\
\hline Kandhari & 2.63 & 1.71 & 1.75 & 40 & 157 & 9.80 \\
\hline Ganesh & 2.27 & 1.85 & 1.83 & $46^{*}$ & 158 & 8.80 \\
\hline Dholka & 2.55 & 1.46 & 1.57 & $47 *$ & 153 & 8.70 \\
\hline Bedana & 2.50 & 1.65 & 1.76 & 48 & 143 & 8.40 \\
\hline Kabuli Kandhari & 2.55 & 1.75 & 1.80 & 46 & 160 & 9.00 \\
\hline G-137 & 2.20 & 1.74 & 1.72 & $46^{*}$ & 148 & 8.23 \\
\hline Jalore Seedless & 2.50 & 1.49 & 1.52 & $49 *$ & 164 & 8.16 \\
\hline Local Selection & 2.13 & 1.25 & 1.32 & 42 & 168 & 4.22 \\
\hline C.D & 0.21 & 0.08 & 0.08 & - & - & 0.46 \\
\hline
\end{tabular}

*Few flowers kept on appearing 
Table.2 Physico-chemical characters of different pomegranate cultivars

\begin{tabular}{|l|c|c|c|c|c|c|c|c|}
\hline \multicolumn{1}{|c|}{ Cultivar } & $\begin{array}{c}\text { Fruit } \\
\text { weight } \\
(\mathbf{g})\end{array}$ & $\begin{array}{c}\text { Fruit } \\
\text { length } \\
(\mathbf{m m})\end{array}$ & $\begin{array}{c}\text { Fruit } \\
\text { breadth } \\
(\mathbf{m m})\end{array}$ & $\begin{array}{c}\text { No. of arils } \\
\text { per fruit }\end{array}$ & $\begin{array}{c}\text { TSS } \\
\mathbf{( \% )}\end{array}$ & $\begin{array}{c}\text { Total } \\
\text { sugars } \\
(\mathbf{\%})\end{array}$ & $\begin{array}{c}\text { Acidity } \\
(\mathbf{\%})\end{array}$ & $\begin{array}{c}\text { Ascorbic } \\
\text { acid } \\
\mathbf{m g} / \mathbf{1 0 0 m l}\end{array}$ \\
\hline Kandhari & 280 & 7.20 & 6.30 & 407 & 15.60 & 8.98 & 0.52 & 11.64 \\
\hline Ganesh & 296 & 7.60 & 7.30 & 410 & 14.55 & 8.70 & 0.40 & 10.82 \\
\hline Dholka & 290 & 7.58 & 7.24 & 395 & 15.32 & 8.84 & 0.48 & 10.05 \\
\hline Bedana & 290 & 7.58 & 7.18 & 381 & 14.40 & 8.77 & 0.42 & 10.44 \\
\hline Kabuli Kandhari & 274 & 7.20 & 6.25 & 402 & 15.45 & 8.64 & 0.54 & 11.02 \\
\hline G-137 & 294 & 7.60 & 7.32 & 422 & 14.62 & 9.02 & 0.44 & 10.54 \\
\hline Jalore Seedless & 272 & 7.46 & 7.08 & 366 & 14.30 & 8.70 & 0.50 & 10.20 \\
\hline Local Selection & 132 & 6.05 & 5.90 & 320 & 12.50 & 8.45 & 5.80 & 9.42 \\
\hline C.D. & 13.35 & 0.22 & 0.17 & 8.72 & 0.66 & 0.26 & 0.09 & 0.20 \\
\hline
\end{tabular}

Table.3 Incidence of fruit cracking and anar butterfly

\begin{tabular}{|l|c|c|}
\hline Cultivar & Incidence of fruit cracking (\%) & Incidence of fruit borer (\%) \\
\hline Kandhari & 18.40 & 17.25 \\
\hline Ganesh & 28.50 & 20.25 \\
\hline Dholka & 25.57 & 15.00 \\
\hline Bedana & 22.25 & 15.27 \\
\hline Kabuli Kandhari & 20.75 & 16.85 \\
\hline G-137 & 28.00 & 18.78 \\
\hline Jalore Seedless & 26.10 & 16.00 \\
\hline Local Selection & 20.69 & 25.00 \\
\hline C.D. & 4.50 & 0.07 \\
\hline
\end{tabular}

The minimum acidity was observed as $0.40 \%$ in Ganesh whereas maximum was recroded as $0.52 \%$ in Kandhari. Considerable variation in titratable acidity of different cultivars has reported by different researchers. Though acid content in fruit is also a varietal character but, Shulman et al., (1984) reported that acid content of pomegranate fruit is also influenced by the harvesting stage and prevailing temperature at the time of fruit maturity. The highest ascorbic content of $11.64 \mathrm{mg} / 100 \mathrm{ml}$ was recorded in $\mathrm{cv}$. Kandhari which was statistically above all the cultivars. The minimum ascorbic acid content was recorded as $9.42 \mathrm{mg} / 100 \mathrm{ml}$ in Local Selection.
Incidence of fruit cracking and fruit borer

Table 3 shows the losses due to incidence of fruit cracking and anar butterfly were huge, however different cultivars showed different susceptibility towards cracking and anar butterfly. Yuan et al., (2010) also reported fruit cracking percentage to vary between 1.5 - $45.9 \%$ in different cultivars. The fruit cracking percentage ranged between $18.40 \%$ in Kandhari $28.50 \%$ in Ganesh which was closely followed by G-137 and Jalore Seedless. Incidence of fruit borer ranged between $15.00 \%$ in Dholka to $25.00 \%$ in Local Selection. Cultivars Ganesh and G-137 also showed huge losses due to fruit borer. 


\section{References}

Anonymous 2019. National Horticulture Board Database.

http://nhb.gov.in/statistics/State_Level/20 17-18-(Final).pdf

AOAC 1995. Official methods of analysis. Association of official analytical chemists. $16^{\text {th }}$ edition. 1220p.

Gil MI, Tomas Barberan FA, Hess-Pierce B, Holcroft DM and Kader AA 2000. Antioxidant activity of pomegranate juice and its relationship with phenolic composition and processing. Journal of Agriculture and Food Chemistry 48(10): 4581-4589.

Hamouda HA, Ibrahim GE and Hafez Omaima M 2014. Nutritional status, fruit quality and volatile compounds in eight Egyptian pomegranate cultivars. British Journal of Applied Science and Technology 4(22): 3263- 3280.

Hertog, MGL, Van Popel G and Verhoeven D 1997. Potentially anticarcinogenic secondary metabolites from fruits and vegetables. In: Phytochemistry of fruits and vegetables. Eds. Tomas -Barberan F.A., Robins, R.J. Oxford, U.K., Claredon press. pp. 313-329.

Jadhav, VT., and Sharma J 2007. Pomegranate cultivation is very promising. Indian Horticulture pp. 30-31.

Mir, MM, Sofi AA, Singh DB and Khan FU 2007. Evaluation of pomegranate cultivars under temperate conditions of Kashmir valley. Indian Journal of Horticulture 64(2): 150-154.

Patil, AV., and Karale AR 1992. Pomegranate. In: Fruits of India - Tropical and sub-tropical. Bose, T.K. and Mitra, S.K. (Eds.). Naya Prakash, Calcutta. pp. 537- 548.

Ranganna, S., 2001. Hand book of analysis and quality control of fruit and vegetable products. Tata McGraw Hill Pub. Co. Ltd., New Delhi.

Rosenblat, M., and Aviram M 2006. Antioxidative properties of pomegranate: In vitro studies. In: Pomegranate: Ancient roots to modern medicine. Seeram, N. P. and Heber, D. (eds.). Taylor and Francis Group, New York, USA, pp.31-43.

Sharma, N., and Bist HS 2005. Evaluation of some pomegranate cultivars under mid hills of Himachal Pradesh. Acta Horticulturae 696: 103-105.

Shulman, Y., Fainberstein L and Lavee S 1984. Pomegranate fruit development and maturation. Journal of Horticulture Science 59: 265-274.

Sinha, S., 2014. Characterization and evaluation of some newly introduced pomegranate (Punica granatum 1.) germplasm accessions. M.Sc. thesis submitted to Dr YS Parmar University of Horticulture and Forestry, Nauni, Solan, HP. 79p.

Wani, IA., Bhat MY, Lone AA, Banday FA, Khan IA and Ganai Shaiq A 2012. Variation in some promising selections of wild pomegranate (Punica granatum L.) in central Kashmir. Applied Biological Research 14(2) 211- 214.

Westwood MN 1978. Temperate Zone Pomology. W.H. Freeman and Company, San Francisco.

Wetzstein, HY., Zhang Z, Ravid N and Wetzstein ME 2011. Characterization of attributes related to fruit size in pomegranate. HortScience 46(6): 908-912.

Yuan, ZH., Yin YL, Feng LJ Zhao XQ, Hou LF, Zhang YX 2010. Evaluation of pomegranate bagging and fruit cracking in Shandong, China. Acta Horticulturae 940: 163-166.

\section{How to cite this article:}

Deep Ji Bhat, V.K. Wali, Nirmal Sharma, Parshant Bakshi, Mahital Jamwal and Rajesh Kumar. 2019. Performance of Pomegranate (Punica granatum L.) Cultivars under Subtropical Conditions of Jammu, India. Int.J.Curr.Microbiol.App.Sci. 8(07): 2788-2793. doi: https://doi.org/10.20546/ijcmas.2019.807.348 